\title{
RELATIONSHIP BETWEEN THE STREAMFLOWS AND PRECIPITATIONS IN ITAPEMIRIM RIVER BASIN
}

\author{
Natalia Gomes de Souza Mendes ${ }^{1}$, Roberto Avelino Cecílio ${ }^{2 *}$, Sidney Sara Zanetti², Cleber Assis dos Santos ${ }^{3}$ \\ ${ }^{1}$ Federal University of Espírito Santo, Graduate Program in Forestry Sciences, Jerônimo Monteiro, ES, Brazil - n.gsmendes@ gmail.com \\ ${ }^{2}$ Federal University of Espírito Santo, Department of Forestry and Wood Sciences, Jerônimo Monteiro, ES, Brazil - roberto.cecilio@ufes.br \\ sidney.zanetti@ufes.br \\ ${ }^{3}$ National Institute of Spatial Research, Graduate Program in Earth System Sciences, São José dos Campos, SP, Brazil - \\ cleberassis.ufpa@gmail.com
}

Received for publication: 18/07/2017 - Accepted for publication: 24/09/2018

\begin{abstract}
The present paper analyzed the relationship between streamflow and rainfall at the stream of Itapemirim River Watershed (BHRI). The minimum streamflow with duration of seven days $\left(\mathrm{Q}_{7}\right)$, the average annual streamflow $\left(Q_{\text {med }}\right)$ and the annual maximum streamflow $\left(Q_{\max }\right)$ of 11 BHRI's sub-basins were determined. Trends in rainfall and streamflow series were analyzed with Mann-Kandall and Pettitt nonparametric tests. Regression analysis between rainfall and streamflow were established. Results showed no trends on rainfall and $\mathrm{Q}_{7}$ series. Trends in $\mathrm{Q}_{\text {med }}$ were found only at one sub-basin and trends in $\mathrm{Q}_{\max }$ were found in two sub-basins. The total rainfall was correlated with the streamflow of all the sub-basins. It has been found that annual rainfall amount $(\mathrm{Pa})$ explained considerably variations in $\mathrm{Q}_{\mathrm{med}}$ and $\mathrm{Q}_{7}$. Rainfall amounts of the rainiest month $\left(\mathrm{P}_{\max }\right)$ showed good correlation to Qmax.

Keywords: stationarity, basic flow, surface runoff
\end{abstract}

\section{Resumo}

Relação entre as vazões e as precipitações na bacia hidrográfica do rio Itapemirim. O presente trabalho teve por objetivo analisar a relação entre as vazões de cursos d'águas da bacia hidrográfica do rio Itapemirim (BHRI) e a precipitação pluviométrica. Determinaram-se, para as 11 sub-bacias da BHRI, a vazão mínima média com sete dias de duração $\left(\mathrm{Q}_{7}\right)$, a vazão média anual $\left(\mathrm{Q}_{\mathrm{med}}\right)$ e a vazão máxima anual $\left(\mathrm{Q}_{\max }\right)$. A fim de verificar a ocorrência de tendências significativas e/ou mudanças bruscas nas séries de vazão e precipitação, aplicaram-se os testes de Mann-Kendall e de Pettitt. Para a análise da relação entre chuvas e vazões foram realizadas análises de regressão. Com relação às tendências, os resultados mostram que as precipitações e a $\mathrm{Q}_{7}$ se mostraram estacionárias em todas as sub-bacias. A Qmed não foi estacionária apenas em uma e a Qmax em duas das subbacias. $\mathrm{O}$ total precipitado possui forte correlação com as vazões das sub-bacias estudadas. Verificou-se que as chuvas anuais $\left(\mathrm{P}_{\mathrm{a}}\right)$ atuaram de forma considerável para as variações das $\mathrm{Q}_{\text {med }}$ e $\mathrm{Q}_{7}$. As chuvas do mês mais chuvoso $\left(\mathrm{P}_{\max }\right)$ mostraram boa correlação com a $\mathrm{Q}_{\max }$.

Palavras-chave: estacionaridade, escoamento de base, escoamento superficial.

\section{INTRODUÇÃOO}

Although water is a renewable natural resource, the environmental problems related to its distribution and availability are increasingly present today. Among the problems that aggravate stress and water scarcity in many regions of the planet are changes in water availability and increased demand associated with global changes, with extreme hydrological events that increase the vulnerability of the human population and compromise the food security (HOEKSTRA et al., 2012).

The flow regime is capable of integrating several components of a river basin. This hydrological variable has a variation in time and can be directly influenced by the climate (mainly by precipitation), basin physical characteristics and anthropic alterations, such as the changes in the use and occupation of the soil and damming of fluvial waters (DIAS et al., 2015; FREDERICE; BRANDÃO, 2016, RODRIGUEZ, et al., 2010, SALEMI et al., 2013). Its knowledge is a fundamental subsidy for planning and decision making in relation to the use rationalization and conservation of water resources (CRUZ; TUCCI, 2008).

In river basins, the supplying of water from precipitation triggers a series of internal processes. Being the main ones, infiltration, surface and subsurface storage in the soil, surface draining, runoff, weather conditions and erosive processes, which interact constantly between themselves. As for its performance in the river water regime, the precipitation volume strongly influences the dynamics of its flows, reflecting in the behavior of this variable during periods of droughts or floods. Some studies have verified that trends observed in river basin flows were 
explained by variations in rainfall regimes (ESPINOZA VILLAR et al., 2009; KREPPER et al., 2008; SANTOS et al., 2010).

In recent years, accumulated annual rainfall in the state of Espírito Santo, Brazil, has been below average in many regions, leading to losses of several orders, from agriculture to domestic and industrial supplies. Facing this, some measures to ensure supply were taken, such as water supply companies prioritizing service to the population (as recommended in Article 1 of Law 9,433) and reviewing their contracts with the industrial sector, in addition to restriction or prohibition of irrigation in some municipalities during droughts. In this sense, the hydrographic Itapemirim River Basin (BHRI), as well as others in the State, had their water availability changed due to the droughts at the present time. At BHRI, part of their municipalities decreed a water emergency in 2015.

From the foregoing, the present study aims to analyze the behavior of the BHRI watercourse flows and relating them to the rainfall precipitation behavior.

\section{MATERIAL E METHODS}

\section{Area under study}

The study area comprises the Itapemirim river basin, located in the southern region of the state of Espírito Santo (Figure 1A), between the meridians $40^{\circ} 48^{\prime}$ and $41^{\circ} 52^{\prime}$ West longitude and between the parallels $20^{\circ} 10^{\prime}$ and $21^{\circ} 15^{\prime}$ South latitude. It has a total area of approximately $5,920 \mathrm{~km}^{2}$, and it covers eighteen municipalities in the state of Minas Gerais and part of the municipality of Lajinha.

According to the classification of Köppen, the predominant climatic types in BHRI are "Cwa" Subtropical dry winter climate (with temperatures below $18^{\circ} \mathrm{C}$ ) and hot summer (with temperatures over $22^{\circ} \mathrm{C}$ ) and " $C w b$ " - Subtropical altitude climate, with dry winter and warm summer (ALVARES et al., 2013).

The vegetation in the study area is within the areas of the Atlantic Forest biome, in the following formations: Submontane Dense Ombrophylous Forest, Montane and Altomontane; and Semidecidual Seasonal Forest of Lowlands and Submontane.

\section{Hydrological data}

The daily historical series of 11 fluviometric stations (Figure 1B) located in the BHRI and 29 rainfall stations (Figure 1C) were obtained from Hydrological Information System of ANA - Hidroweb (Agência Nacional de Águas, 2016) for BHRI and adjacent areas. The collection period of the data series was related to the hydrological years between 1984/1985 and 2013/2014. The BHRI was subdivided into sub-basins relating to the contribution areas of each of the 11 fluviometric stations.

For each of the fluviometric stations, the average minimum flow rate within 7 days $\left(\mathrm{Q}_{7}\right)$, mean annual flow $\left(\mathrm{Q}_{\mathrm{med}}\right)$ and maximum annual flow $\left(\mathrm{Q}_{\max }\right)$ were obtained for each hydrological year. The determination of the respective flows was carried out using software HIDRO 1.2.1 (Agência Nacional de Águas, 2016), considering the hydrological year beginning in October and ending in September. The rainfall data for each sub-basin were used to obtain, for each hydrological year, the following rainfall: monthly maximum $\left(\mathrm{P}_{\max }\right)$, monthly minimum $\left(\mathrm{P}_{\mathrm{min}}\right)$, rainiest semester $\left(\mathrm{P}_{\mathrm{sc}}\right)$, of the summer $\left(\mathrm{P}_{\text {summer }}\right)$ and the annual total $\left(\mathrm{P}_{\mathrm{a}}\right)$.

\section{Statistical analysis}

In order to verify the occurrence of significant trends and/or abrupt changes in the flow series $\left(\mathrm{Q}_{7}, \mathrm{Q}_{\mathrm{med}}\right.$ and $\mathrm{Q}_{\max }$ ) and precipitation $\left(\mathrm{P}_{\max }, \mathrm{P}_{\min }, \mathrm{P}_{\mathrm{sc}}, \mathrm{P}_{\text {summer }}\right.$ and $\mathrm{P}_{\mathrm{a}}$ ) Mann-Kendall non-parametric statistical tests, as recommended by the World Meteorological Organization (SENA; LUCENA, 2013), and Pettitt (PETTITT, 1979), both with a significance level of $1 \%$ were used for each sub-basin.

Subsequently, associations were performed for each sub-basin under study by regression analysis between the dependent variables $\left(\mathrm{Q}_{\text {med }}, \mathrm{Q}_{7}\right.$ and $\left.\mathrm{Q}_{\max }\right)$ and the independent variables $\left(\mathrm{P}_{\max }, \mathrm{P}_{\min }, \mathrm{P}_{\mathrm{sc}}, \mathrm{P}_{\text {summer }}\right.$, and $\left.\mathrm{P}_{\mathrm{a}}\right)$, as was done in other studies (LATUF, 2007; SANTOS, et al., 2010). Only the following associations of dependent variables with independent variables were analyzed: $Q_{\text {med }}$ with $P_{a} ; Q_{7}$ with $P_{\min }, P_{s c}, P_{s u m m e r}$, and $P_{a}$; and $Q_{\max }$ with $\mathrm{P}_{\max }$. In the regressions, the adjustments of the linear and quadratic functions were tested in order to verify in which of the functions the relation between the variables was significant by the test $\mathrm{F}$ at $1 \%$ of probability. 
A

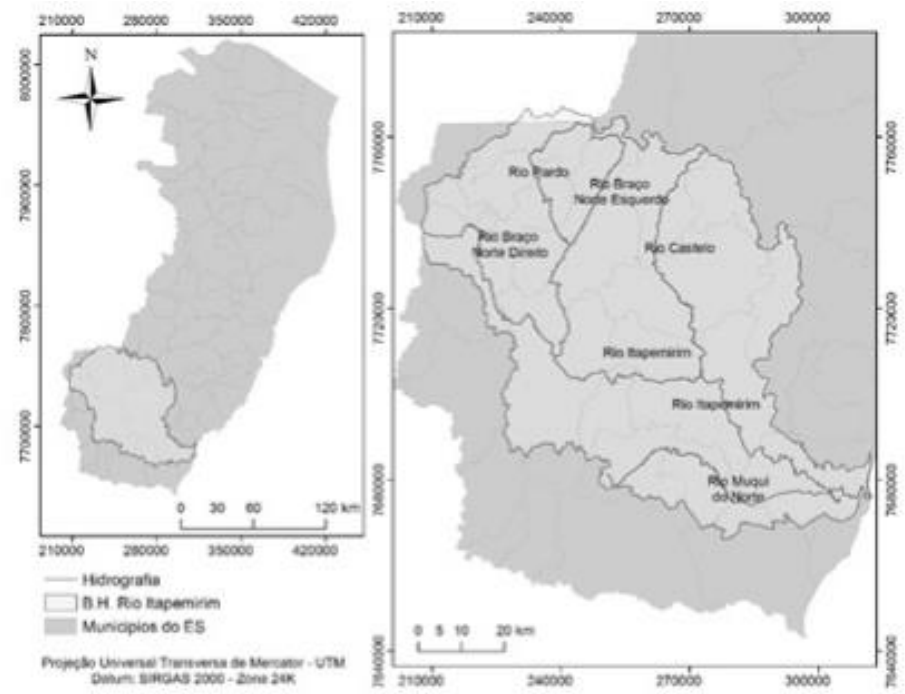

B

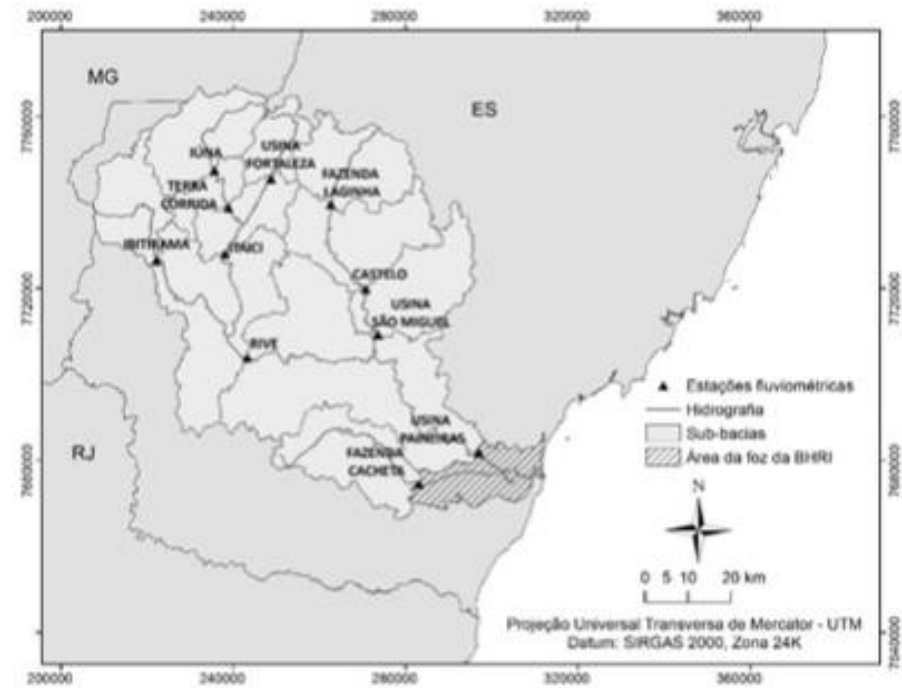

C

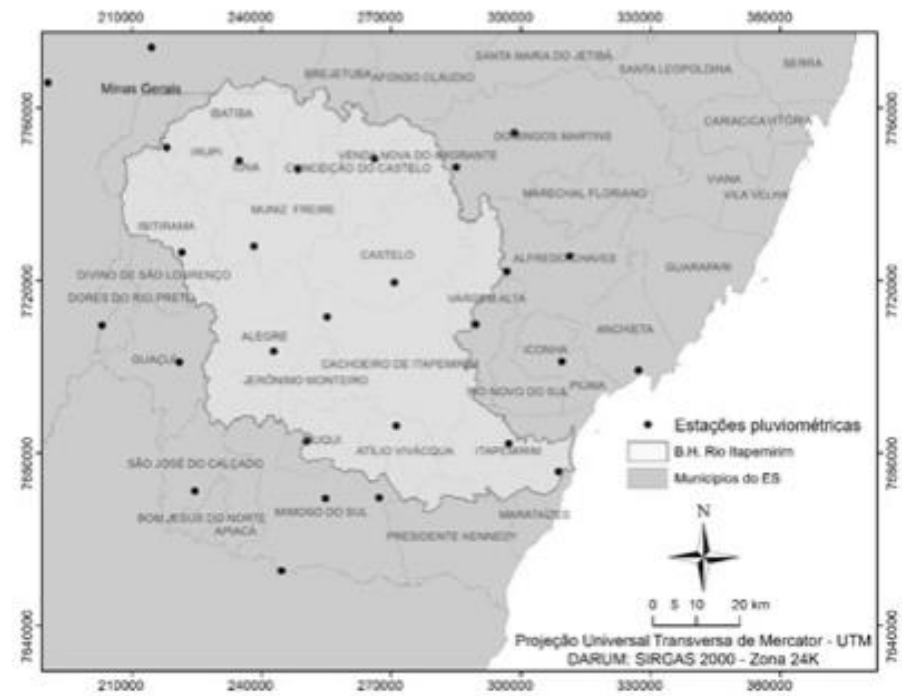

Figure 1. Location of: Itapemirim river watershed at Espírito Santo State (A), stream gauge stations and its subbasins (B), and rain gauge station used in this paper (C).

Figura 1. Mapas de localização: da bacia hidrográfica do rio Itapemirim no Espírito Santo (A), das estações fluviométricas e suas sub-bacias (B) e das estações pluviométricas analisadas (C). 


\section{RESULTS}

Tables 1 and 2 show the results of the non-parametric Mann-Kendall test (p-value and trend slope) for the precipitation and flow series of each sub-basin studied. In these, the p-value less than 0.01 indicates that there is no monotonic tendency statistically significant in the series at $1 \%$ probability. Regarding to the slope tendency, calculated according to the method of Sen (SEN, 1968), positive values indicate a tendency of increase and negatives of decrease from the precipitation averages or flow over the years.

Table 1. Trend analysis (Mann-Kendall test) and abrupt changes (Pettitt Test) in the rainfall series of each Itapemirim river sub-basins.

Tabela 1. Análise de tendência (Teste de Mann-Kendall) e de mudanças bruscas (Teste de Pettitt) nas séries de precipitação nas sub-bacias do Rio Itapemirim.

\begin{tabular}{|c|c|c|c|c|c|c|c|c|c|c|c|c|c|c|c|}
\hline \multirow{3}{*}{ Sub-basin } & \multicolumn{10}{|c|}{ Mann-Kendall test } & \multirow{2}{*}{\multicolumn{5}{|c|}{$\begin{array}{c}\text { Pettitt test } \\
\text { p-value }\end{array}$}} \\
\hline & \multicolumn{5}{|c|}{ p-value } & \multicolumn{5}{|c|}{$\begin{array}{l}\text { Trend slope } \\
\left(\text { mm year }^{-1}\right)\end{array}$} & & & & & \\
\hline & $\mathrm{P}_{\mathrm{a}}$ & $\mathrm{P}_{\max }$ & $\mathrm{P}_{\min }$ & $\mathrm{P}_{\mathrm{sc}}$ & $\mathrm{P}_{\text {summer }}$ & $\mathrm{P}_{\mathrm{a}}$ & $\mathrm{P}_{\max }$ & $\mathrm{P}_{\min }$ & $\mathrm{P}_{\mathrm{sc}}$ & $\mathrm{P}_{\text {summer }}$ & $\mathrm{P}_{\mathrm{a}}$ & $\mathrm{P}_{\max }$ & $\mathrm{P}_{\min }$ & $\mathrm{P}_{\mathrm{sc}}$ & $\mathrm{P}_{\text {summer }}$ \\
\hline Castelo & 0.26 & 0.02 & 0.75 & 0.12 & 0.38 & 3.37 & 3.96 & 0.04 & 4.99 & 2.89 & 0.20 & 0.04 & 0.30 & 0.20 & 0.48 \\
\hline Fazenda Cacheta & 0.80 & 0.05 & 0.26 & 0.38 & 0.46 & 2.99 & 4.98 & 0.21 & 6.12 & 3.19 & 0.62 & 0.27 & 0.99 & 0.71 & 0.57 \\
\hline Fazenda Laginha & 0.23 & 0.04 & 0.75 & 0.07 & 0.36 & 3.39 & 4.34 & -0.04 & 5.14 & 3.28 & 0.05 & 0.10 & 0.91 & 0.07 & 0.44 \\
\hline Iúna & 0.24 & 0.03 & 0.65 & 0.12 & 0.52 & 3.70 & 4.84 & -0.08 & 5.10 & 3.29 & 0.55 & 0.12 & 0.97 & 0.09 & 0.98 \\
\hline Ibitirama & 0.29 & 0.02 & 0.83 & 0.09 & 0.62 & 5.08 & 4.54 & 0.03 & 6.92 & 1.89 & 0.27 & 0.04 & 0.55 & 0,20 & 1.00 \\
\hline Itaici & 0.29 & 0.02 & 0.80 & 0.10 & 0.60 & 4.20 & 4.95 & -0.02 & 6.27 & 2.04 & 0.58 & 0.07 & 0.89 & 0.18 & 0.81 \\
\hline Rive & 0.26 & 0.01 & 0.80 & 0.17 & 0.62 & 3.68 & 4.99 & 0.05 & 6.24 & 1.91 & 0.49 & 0.03 & 0.41 & 0.29 & 0.95 \\
\hline Terra Corrida & 0.29 & 0.02 & 0.62 & 0.10 & 0.50 & 4.04 & 5.07 & -0.06 & 5.52 & 2.15 & 0.61 & 0.09 & 0.99 & 0.09 & 0.98 \\
\hline Usina Fortaleza & 0.21 & 0.02 & 0.98 & 0.11 & 0.44 & 3.53 & 4.33 & 0.01 & 6.14 & 2.27 & 0.16 & 0.07 & 0.89 & 0.14 & 0.72 \\
\hline Usina Paineiras & 0.40 & 0.01 & 0.30 & 0.30 & 0.65 & 3.14 & 4.56 & 0.15 & 6.22 & 1.96 & 0.62 & 0.07 & 0.75 & 0.56 & 0.94 \\
\hline Usina São Miguel & 0.23 & 0.02 & 0.34 & 0.16 & 0.60 & 3.81 & 4.23 & 0.12 & 6.02 & 1.83 & 0.27 & 0.06 & 0.74 & 0.36 & 0.91 \\
\hline
\end{tabular}

Table 2. Trend analysis (Mann-Kendall test) and abrupt changes (Pettitt Test) in the average annual streamflow $\left(\mathrm{Q}_{\mathrm{med}}\right)$, the minimum streamflow with duration of seven days $\left(\mathrm{Q}_{7}\right)$, and the annual maximum streamflow $\left(\mathrm{Q}_{\max }\right)$ series of each Itapemirim river sub-basins

Tabela 2. Análise de tendência (Teste de Mann-Kendall) e de mudanças bruscas (Teste de Pettitt) séries de vazões anuais média $\left(\mathrm{Q}_{\mathrm{med}}\right)$, mínima média com sete dias de duração $\left(\mathrm{Q}_{7}\right)$ e máxima $\left(\mathrm{Q}_{\max }\right)$ nas sub-bacias do Rio Itapemirim.

\begin{tabular}{|c|c|c|c|c|c|c|c|c|c|}
\hline \multirow{3}{*}{ Sub-basin } & \multicolumn{6}{|c|}{ Mann-Kendall test } & \multirow{2}{*}{\multicolumn{3}{|c|}{$\begin{array}{c}\text { Pettitt test } \\
\text { p-value }\end{array}$}} \\
\hline & \multicolumn{3}{|c|}{ p-value } & \multicolumn{3}{|c|}{$\begin{array}{c}\text { Slope trend } \\
\left(\mathbf{m}^{3} \mathbf{s}^{-1} \text { year }^{-1}\right)\end{array}$} & & & \\
\hline & $Q_{\text {med }}$ & $\mathbf{Q}_{7}$ & $\mathbf{Q}_{\max }$ & $\mathbf{Q}_{\text {med }}$ & $\mathbf{Q}_{7}$ & $\mathbf{Q}_{\max }$ & Qmed & $\mathbf{Q}_{7}$ & $\mathbf{Q}_{\max }$ \\
\hline Castelo & 0.30 & 0.12 & $<0.01$ & 0.11 & -0.05 & 3.50 & 0.06 & 0.07 & 0.01 \\
\hline Fazenda Cacheta & $<0.01$ & 0.20 & 0.01 & 0.17 & 0.03 & 1.92 & 0.02 & 0.05 & $<0.01$ \\
\hline Fazenda Laginha & 0.89 & 0.08 & 0.32 & -0.01 & -0.03 & 0.54 & 0.85 & 0.09 & 0.19 \\
\hline Iúna & 0.89 & 0.55 & $<0.01$ & 0.01 & -0.02 & 1.07 & 0.76 & 0.44 & 0.02 \\
\hline Ibitirama & 0.24 & 0.17 & 0.14 & 0.07 & -0.01 & 1.57 & 0.37 & 0.25 & 0.54 \\
\hline Itaici & 0.62 & 0.36 & 0.05 & 0.05 & -0.04 & 2.53 & 0.60 & 0.41 & 0.21 \\
\hline Rive & 0.26 & 0.50 & 0.02 & 0.36 & 0.04 & 9.13 & 0.34 & 0.32 & 0.15 \\
\hline Terra Corrida & 0.18 & 0.87 & 0.02 & 0.10 & 0.01 & 1.97 & 0.15 & 0.50 & 0.05 \\
\hline Usina Fortaleza & 0.72 & 0.04 & 0.05 & -0.01 & -0.02 & 0.74 & 0.51 & 0.32 & 0.02 \\
\hline Usina Paineiras & 0.48 & 0.24 & 0.04 & 0.33 & -0.23 & 5.33 & 0.42 & 0.34 & 0.09 \\
\hline Usina São Miguel & 0.57 & 0.08 & 0.01 & 0.08 & -0.09 & 3.68 & 0.18 & 0.04 & 0.05 \\
\hline
\end{tabular}


Table 3 shows the results of the regression analysis between the precipitation flows. It is emphasized that only the pertinent relations are presented to the type of precipitation in which the relation with the flow was significant with a level of $1 \%$ of test $\mathrm{F}$.

Table 3. Regression equation to estimate the average annual streamflow $\left(Q_{m e d}\right)$, the minimum streamflow with duration of seven days $\left(\mathrm{Q}_{7}\right)$, and the annual maximum streamflow $\left(\mathrm{Q}_{\max }\right)$ of the Itapemirim river subbasins where significant correlations with rainfall were found ( $\mathrm{F}$ test at $1 \%$ ).

Tabela 4. Equações para estimativa das vazões anuais média $\left(\mathrm{Q}_{\mathrm{med}}\right)$, mínima média com sete dias de duração $\left(\mathrm{Q}_{7}\right)$ e máxima $\left(Q_{\max }\right)$ nas sub-bacias do Rio Itapemirim para as quais houve correlação significativa com diferentes precipitações, pelo teste $\mathrm{F}$ a $1 \%$.

\begin{tabular}{|c|c|c|c|}
\hline Sub-basin & $\begin{array}{c}\text { Flow } \\
\left(\mathbf{m}^{3} \mathbf{s}^{-1}\right)\end{array}$ & Regression Equations & $\mathbf{R}^{2}$ \\
\hline \multirow{3}{*}{ Castelo } & $\mathrm{Q}_{\mathrm{med}}$ & $Q_{\text {med }}=0,00002 P_{a}^{2}-0,0238 P_{a}+16,988$ & 0.81 \\
\hline & $\mathrm{Q}_{7}$ & $\mathrm{Q}_{7}=0,000007 \mathrm{P}_{\mathrm{a}}^{2}-0,0163 \mathrm{P}_{\mathrm{a}}+12,401$ & 0.36 \\
\hline & $\mathrm{Q}_{\max }$ & $\mathrm{Q}_{\max }=-0,002 \mathrm{P}_{\max }^{2}+1,8912 \mathrm{P}_{\max }-221,6$ & 0.43 \\
\hline \multirow{3}{*}{ Fazenda Cacheta } & $\mathrm{Q}_{\mathrm{med}}$ & $\mathrm{Q}_{\text {med }}=0,000004 \mathrm{P}_{\mathrm{a}}^{2}-0,0019 \mathrm{P}_{\mathrm{a}}+2,6627$ & 0.36 \\
\hline & $\mathrm{Q}_{7}$ & - & - \\
\hline & $\mathrm{Q}_{\max }$ & $\mathrm{Q}_{\max }=-0,0006 \mathrm{P}_{\max }^{2}+0,5466 \mathrm{P}_{\max }-45,133$ & 0.34 \\
\hline \multirow{3}{*}{ Fazenda Laginha } & $\mathrm{Q}_{\mathrm{med}}$ & $\mathrm{Q}_{\text {med }}=0,000007 \mathrm{P}_{\mathrm{a}}^{2}-0,0109 \mathrm{P}_{\mathrm{a}}+8,9121$ & 0.67 \\
\hline & $\mathrm{Q}_{7}$ & $\mathrm{Q}_{7}=0,000004 \mathrm{P}_{\mathrm{a}}^{2}-0,0086 \mathrm{P}_{\mathrm{a}}+6,0484$ & 0.50 \\
\hline & $\mathrm{Q}_{\max }$ & $\mathrm{Q}_{\max }=-0,0013 \mathrm{P}_{\max }^{2}+1,0959 \mathrm{P}_{\max }-122,46$ & 0.52 \\
\hline \multirow{3}{*}{ Iúna } & $\mathrm{Q}_{\mathrm{med}}$ & - & - \\
\hline & $\mathrm{Q}_{7}$ & - & - \\
\hline & $Q_{\max }$ & - & - \\
\hline \multirow{3}{*}{ Ibitirama } & $\mathrm{Q}_{\text {med }}$ & $\mathrm{Q}_{\text {med }}=0,000002 \mathrm{P}_{\mathrm{a}}^{2}+0,0044 \mathrm{P}_{\mathrm{a}}+0,4493$ & 0.65 \\
\hline & $\mathrm{Q}_{7}$ & $\mathrm{Q}_{7}=0,000002 \mathrm{P}_{\mathrm{a}}^{2}-0,0037 \mathrm{P}_{\mathrm{a}}+3,628$ & 0.50 \\
\hline & $\mathrm{Q}_{\max }$ & - & - \\
\hline \multirow{3}{*}{ Itaici } & $\mathrm{Q}_{\text {med }}$ & $Q_{\text {med }}=0,00001 P_{a}^{2}-0,0114 P_{a}+10,386$ & 0.77 \\
\hline & $\mathrm{Q}_{7}$ & $\mathrm{Q}_{7}=0,000005 \mathrm{P}_{\mathrm{a}}^{2}-0,0092 \mathrm{P}_{\mathrm{a}}+8,0812$ & 0.50 \\
\hline & $\mathrm{Q}_{\max }$ & $\mathrm{Q}_{\max }=-0,0031 \mathrm{P}_{\max }^{2}+2,658 \mathrm{P}_{\max }-330,86$ & 0.48 \\
\hline \multirow{3}{*}{ Rive } & $\mathrm{Q}_{\text {med }}$ & $\mathrm{Q}_{\text {med }}=0,00002 \mathrm{P}_{\mathrm{a}}^{2}-0,0222 \mathrm{P}_{\mathrm{a}}+23,041$ & 0.80 \\
\hline & $\mathrm{Q}_{7}$ & $Q_{7}=0,000008 P_{a}^{2}-0,0118 P_{a}+12,646$ & 0.68 \\
\hline & $\mathrm{Q}_{\max }$ & $\mathrm{Q}_{\max }=-0,0054 \mathrm{P}_{\max }^{2}+4,9924 \mathrm{P}_{\max }-618,43$ & 0.56 \\
\hline \multirow{3}{*}{ Terra Corrida } & $\mathrm{Q}_{\text {med }}$ & $\mathrm{Q}_{\mathrm{med}}=0,000006 \mathrm{P}_{\mathrm{a}}^{2}-0,0036 \mathrm{P}_{\mathrm{a}}+4,0942$ & 0.79 \\
\hline & $\mathrm{Q}_{7}$ & $\mathrm{Q}_{7}=0,000002 \mathrm{P}_{\mathrm{a}}^{2}-0,0009 \mathrm{P}_{\mathrm{a}}+1,7979$ & 0.63 \\
\hline & $\mathrm{Q}_{\max }$ & $\mathrm{Q}_{\max }=-0,0015 \mathrm{P}_{\max }^{2}+1,3835 \mathrm{P}_{\max }-179,49$ & 0.44 \\
\hline \multirow{3}{*}{ Usina Fortaleza } & $\mathrm{Q}_{\text {med }}$ & $Q_{\text {med }}=0,000004 P_{a}^{2}-0,0051 P_{a}+4,954$ & 0.57 \\
\hline & $\mathrm{Q}_{7}$ & - & - \\
\hline & $\mathrm{Q}_{\max }$ & $\mathrm{Q}_{\max }=-0,0005 \mathrm{P}_{\max }^{2}+0,4952 \mathrm{P}_{\max }-49,376$ & 0.46 \\
\hline \multirow{3}{*}{ Usina Paineiras } & $\mathrm{Q}_{\text {med }}$ & $Q_{\text {med }}=0,00005 P_{a}^{2}-0,0364 P_{a}+32,368$ & 0.83 \\
\hline & $\mathrm{Q}_{7}$ & $\mathrm{Q}_{7}=0,00003 \mathrm{P}_{\mathrm{a}}^{2}-0,0637 \mathrm{P}_{\mathrm{a}}+48,763$ & 0.61 \\
\hline & $\mathrm{Q}_{\max }$ & $\mathrm{Q}_{\max }=-0,0025 \mathrm{P}_{\max }^{2}+2,8137 \mathrm{P}_{\max }-129,1$ & 0.60 \\
\hline \multirow{3}{*}{ Usina São Miguel } & $\mathrm{Q}_{\text {med }}$ & $\mathrm{Q}_{\text {med }}=0,00005 \mathrm{P}_{\mathrm{a}}^{2}-0,0202 \mathrm{P}_{\mathrm{a}}+18,021$ & 0.74 \\
\hline & $\mathrm{Q}_{7}$ & $\mathrm{Q}_{7}=0,00001 \mathrm{P}_{\mathrm{a}}^{2}-0,0237 \mathrm{P}_{\mathrm{a}}+19,685$ & 0.50 \\
\hline & $\mathrm{Q}_{\max }$ & - & - \\
\hline
\end{tabular}

$\mathrm{Pa}$ - anual rainfall depth, $\mathrm{mm}$ and Pmax - rainfall depth of the rainiest month, $\mathrm{mm}$.

$\mathrm{Pa}$ - lâmina precipitada anual, mm e Pmax - lâmina precipitada no mês mais chuvoso, mm.

\section{DISCUSSION}

The non-parametric Mann-Kendall and Pettitt tests indicate that all precipitations analyzed $\left(\mathrm{P}_{\max }, \mathrm{P}_{\min }\right.$, $\mathrm{P}_{\mathrm{sc}}, \mathrm{P}_{\text {summer, }}$ and $\left.\mathrm{P}_{\text {anual }}\right)$ had a $\mathrm{p}$ value equal to or greater than 0.01 . That is, during the analyzed period, the series of these precipitations were stationary, with no significant trends occurring or abrupt changes at a significance level of $1 \%$.

By evaluating the relevant results for the Man-Kendall test for flow rates, it is observed that $\mathrm{Q}_{7}$ was stationary in all sub-basins. The $\mathrm{Q}_{\text {med }}$ was not stationary only for Fazenda Cacheta, showing an upward trend of $0.17 \mathrm{~m}^{3} \mathrm{~s}^{-1}$ year $^{-1}$, which corresponds to approximately $2.5 \%$ of $\mathrm{Q}_{\operatorname{med}}$ in this sub-basin. The $\mathrm{Q}_{\max }$ was not stationary 
only for two sub-basins: Castelo (CAS), with a trend of increase of $3.5 \mathrm{~m}^{3} \mathrm{~s}^{-1}$ year-1, and Iúna (IUN), with an increase trend of $1.07 \mathrm{~m}^{3} \mathrm{~s}^{-1}$ year $^{-1} ; 2.1 \%$ and $1.6 \%$ of the maximum flows, respectively. Since there was no significant trend in precipitation behavior in these sub-basins, it is believed that such increases are due to several factors, especially changes in land use.

The $\mathrm{Q}_{\max }$ analysis shows that, although there is a significant trend only for CAS and IUN, trend slope values of all sub-basins were positive, denoting behavior associated with the increase of this variable. In this same line, a study evaluating maximum flows in hydrographic basins of the whole Planet, using the Mann-Kendall Test with a $10 \%$ significance level (DO et al., 2017), found a predominance of significant increasing trend to $Q_{\max }$ in smaller basins (less than $500 \mathrm{Km}^{2}$ ).

Regarding the Pettitt test results, with only one exception, all three outlets in all sub-basins did not show significant sharp changes ( $\mathrm{p}$-value> 0.01) in their values. The exception was the $\mathrm{Q}_{\max }$ behavior in the Fazenda Cacheta (FCA) sub-basin, which showed a trend, with a rupture in the series occurred in 1995, according to Figure 2. A new application of the Mann-Kendall test, using the data before and after the rupture year, does not show a significant trend in the behavior of these flows (p-value equal to 0.38 and 0.90 before and after rupture, respectively). The differences, as not associated with changes in precipitation, may also be due to changes in land use or construction of hydraulic works, for example.

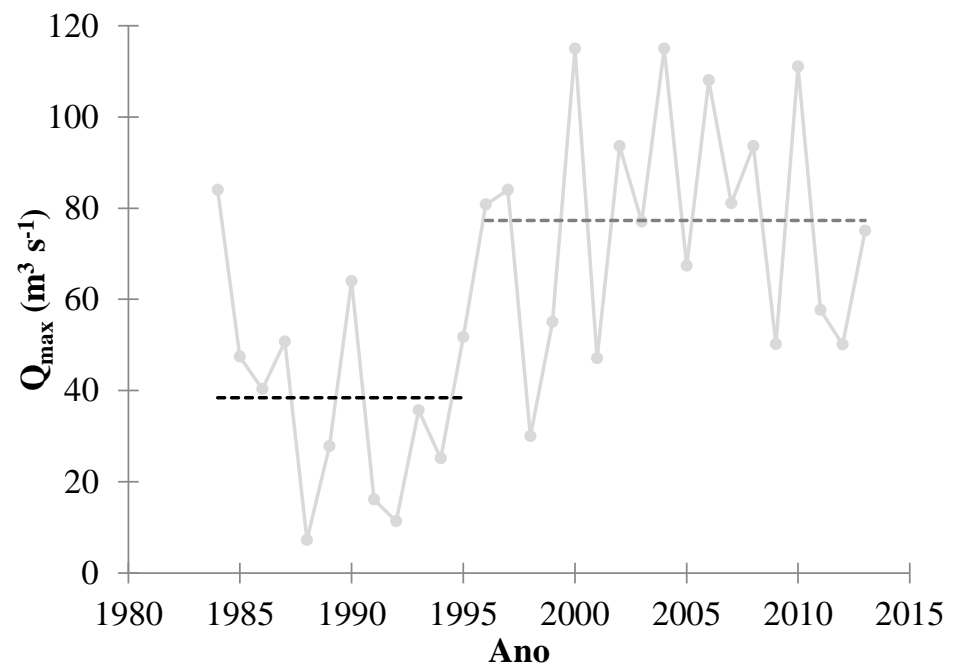

Figure 2. Maximum annual streamflow series of Fazenda Cacheta sub-basin, where average values before (38.4 $\left.\mathrm{m}^{3} \mathrm{~s}^{-1}\right)$ and after $\left(77.3 \mathrm{~m}^{3} \mathrm{~s}^{-1}\right) 1995$ were statistically different according to Pettitt test.

Figura 2. Comportamento da vazão máxima na sub-bacia Fazenda Cacheta, na qual as médias antes $\left(38,4 \mathrm{~m}^{3} \mathrm{~s}^{-1}\right)$ e depois $\left(77,3 \mathrm{~m}^{3} \mathrm{~s}^{-1}\right)$ de 1995 são diferentes de acordo com o Teste de Pettitt.

Regarding the regression equations presented in Table 3, it can be observed that in ten of the 11 subbasins, $\mathrm{P}_{\mathrm{a}}$ satisfactorily explained the variation of $\mathrm{Q}_{\mathrm{med}}$ ( $\mathrm{p}$-value $\left.<0.01\right)$. The sub-basin for the Iúna fluviometric station was the only one in which the correlation between $\mathrm{Q}_{\mathrm{med}}$ and $\mathrm{P}_{\mathrm{a}}$ was not significant at $1 \% \mathrm{~F}$-test. In general, changes in the $\mathrm{Q}_{\mathrm{med}}$ of a large part of the BHRI corresponded directly to the behavior of the annual rainfall, considering the analyzed period. The values of the determination coefficients of these sub-basins ranged from 0.36 (FCA) to 0.83 (Usina Paineiras - UPA), all of which showed a positive trend between $\mathrm{Q}_{\text {med }}$ and $\mathrm{P}_{\text {to }}$, in a way that higher average flows were explained by the annual rainfall performance. Such correlation is justified because precipitation is the primary source of water for the maintenance of hydrological processes in river basins, especially for the deflution of water courses. Once the average flow values were analyzed, integrators of all hydrological behavior during the year, high correlation with the annual total rainfall was effectively expected.

In the same way as presented here, other studies found significant and positive correlations of $\mathrm{Q}_{\text {med }}$ and $\mathrm{P}_{\mathrm{a}}$, as in Paraná River basins (KREPPER et al., 2008) and in the Cerrado Biome basins: Rio Preto and Ribeirão Entre Ribeiros (LATUF, 2007) and Ribeirão João Leite (SANTOS et al., 2010). Similarly, although the same correlation analysis of the present study was not done, some studies suggest a positive relationship between these variables, such as: for the Carmo River basin (BARBOSA et al., 2005) in the vicinity of the Itapemirim river basin; for the sub-basin of the Itacaiúnas River, in the Amazon (ARAUJO; OLIVEIRA, 2013); and for the Alto Amazonas basins (ESPINOZA VILLAR et al., 2009). 
Finally, a compilation of studies on the impact of climate change on water resources (MARENGO, 2008) shows the clear influence of increased precipitation on the increase in average flows in South America, especially in the southeast portion, where the basin under study is located.

In relation to the results of Table 3 , the $\mathrm{Q}_{7}$ of the 11 sub-basins analyzed only showed a significant correlation (1\% significance) with the precipitations, being: eight with $\mathrm{P}_{\mathrm{a}}$, eight with $\mathrm{P}_{\mathrm{sc}}$, seven with $\mathrm{P}_{\text {summer }}$ and none with $\mathrm{P}_{\text {min }}$. The minimum flows in rivers, occurring during periods of drought, reflect the conditions of recharge of the aquifer in previous periods. In this way, the variation regime and accumulated precipitation, together with soil water infiltration conditions, transpiration of the vegetation cover (SANTOS et al., 2010), and local hydrogeology, (COELHO et al., 2015) directly influence these flows. In BHRI, the lack of association of $\mathrm{Q}_{7}$ with $\mathrm{P}_{\min }$ and the best correlations with $\mathrm{P}_{\text {summer }}, \mathrm{P}_{\mathrm{sc}}$ and $\mathrm{P}_{\mathrm{a}}$ are relevant since the recharge of the aquifers happens due to precipitations that occur in all years, with greater influence of those concentrated in the rainy season.

As the precipitation layer accumulated in the year $\left(\mathrm{P}_{\mathrm{a}}\right)$ has a higher magnitude than the others, this was the characteristic of precipitation that contributed most to the variation of $\mathrm{Q}_{7}$, being related to this flow quite expressively ( $p$-value $<0.01$ ), and with the highest $\mathrm{R}^{2}$, in the eight sub-basins where rain correlation was detected with $\mathrm{Q}_{7}$. Precipitations of rainy periods $\left(\mathrm{P}_{\mathrm{sc}}\right.$ and $\left.\mathrm{P}_{\text {summer }}\right)$, of lower magnitude than $\mathrm{P}_{\mathrm{a}}$, also correlate with $\mathrm{Q}_{7}$ of most sub-basins, although with lower $\mathrm{R}^{2}$ (data not shown in Table 3). Cumulative rainfall over longer periods of time ( $\mathrm{P}_{\mathrm{a}}$ or its sum over several years) appears to be as important for the magnitude of $\mathrm{Q}_{7}$, that Mello et al. (2008) propose their use for estimating the impact of climate change on water availability in the Paracatu River basin. Similar results, in which a positive association of $\mathrm{Q}_{7}$ with $\mathrm{P}_{\mathrm{a}}$ was found, were found in the previously mentioned studies, pertinent to the Rio Preto and Ribeirão Entre Rios basins (LATUF, 2007) and to Ribeirão João Leite basin (SANTOS et al., 2010). For the Rio do Carmo basin (belonging to Rio Doce basin), a correlation of $\mathrm{Q}_{7}$ with $\mathrm{P}_{\mathrm{a}}$ and with $\mathrm{P}_{\mathrm{sc}}$ (BARBOSA et al., 2005) was also found.

None of the rains analyzed showed a significant correlation with $\mathrm{Q}_{7}$ of the FCA, IUN and Usina Fortaleza (UFO) sub-basins, with a p-value always higher than 0.09. These sub-basins have the lowest average values of $\mathrm{Q}_{7}$, in relation to the others, being $1.9 \mathrm{~m}^{3} \mathrm{~s}^{-1}$ in FCA, $3.4 \mathrm{~m}^{3} \mathrm{~s}^{-1}$ in IUN, and $1.2 \mathrm{~m}^{3} \mathrm{~s}^{-1}$ in UFO. The lower water availabilities of these areas may also be a reflection of several factors, such as geology, slope, soils, dams or others, which may hinder the storage of water in the subsoil and, therefore, did not cause increases in the flow rates $Q_{7}$ in the drought. However, further studies are needed in relation to this question, just as it is not possible to say about the factors that caused this behavior in the $\mathrm{Q}_{7}$ of IUN and UFO. Thus, characterization studies of the biotic and abiotic factors of these basins are encouraged, so that it can be identified which of the environmental parameters of the river basins are more influential and, among them, which are capable of integrated management aiming at soil and water conservation, which in turn will favor the availability of water during periods of drought.

Due to accumulated annual rainfall or rainfall occurrence have responded by the majority of the variations occurring in flows $\mathrm{Q}_{7}$, this does not mean that this relationship does not exist in the sub-basins of FCA, IUN and UFO, since the BHRI rainfall data consist of interpolated average data, so there is some caution to the statement that the rains analyzed did not influence the flows of these sub-basins.

The data presented in Table 3 show that maximum monthly rainfall analyzed $\left(\mathrm{P}_{\max }\right)$ correlated significantly with $\mathrm{Q}_{\max }$ in eight of 11 sub-basins. Only in the IUN, Ibitirama (IBI) and São Miguel (USM) subbasins $\mathrm{P}_{\max }$ did not significantly correlate with $\mathrm{Q}_{\max }$. In a similar result to that of the present study, Latuf (2007) also verified that the $\mathrm{P}_{\max }$ was the most explanatory variable for the changes occurred in the regime of maximum flows of six among the eight fluviometric stations of the basins of Rio Preto and Ribeirão Entre Ribeiros.

The significant correlation found was expected, since the maximum totals that occur in smaller time intervals are responsible for the generation of greater volume of surface runoff. This, in turn, rapidly raises the flows of watercourses. As an example, recent studies in Brazil has found positive and statistically significant correlations of flood events (when $\mathrm{Q}_{\max }$ occur) and daily and cumulative five-day maximum rainfall (ÁVILA et al., 2016).

In the Ribeirão João Leite basin in the Cerrado Biome, $\mathrm{P}_{\mathrm{a}}$, together with the percentage of natural vegetation, showed a better correlation with $\mathrm{Q}_{\max }$ (SANTOS et al., 2010). Similarly, although the same correlation analysis of the present study was not performed, the correlation of the $\mathrm{Q}_{\max }$ with the $\mathrm{P}_{\mathrm{a}}$ was evidenced to Rio do Carmo basin (BARBOSA et al., 2005).

The results shown point to the possibility of using these rainfall characteristics in the regionalization of flows for BHRI. Although there are already studies in this sense (GASPARINI, 2014; REIS et al., 2013), the present study increased the analysis seeking to correlate precipitation characteristics with each of the flows $\left(Q_{\text {med, }}\right.$, $\mathrm{Q}_{7}$ and $\left.\mathrm{Q}_{\max }\right)$. An alternative to improve the performance of the regionalization equations would be the incorporation of $\mathrm{P}_{\mathrm{a}}$, which showed a significant correlation in all the stations studied.

Finally, relations between flows and rains can be complex due to the effects of flow attenuation, expressive in larger basins, compared to the smaller ones. The variability of the BRHI local meteorological conditions, influenced by the orographic effect of Serra do Caparaó (MELO JÚNIOR et al., 2006), due to climatic 
differences (ALVARES et al., 2013) and different air masses in the formation of rainfall (MINUZZI et al., 2007) also contribute to the variability of the flows in the sub-basins and, consequently, to the greater complexity of the rainfall-related studies. It is considered interesting that this study be deepened, correlating not only precipitation, but also with other climatic variables such as evapotranspiration, besides the land use itself, ecophysiographic and morphometric factors. In this way, it is possible to more adequately subsidize the decision-making process for the conservation and availability of water resources with regularity and sufficiency to meet the required demands.

\section{CONCLUSIONS}

Based on the presented paper, it is concluded that for the analyzed period at BHRI:

- The precipitations were stationary with no significant alteration trends occurring.

- The $\mathrm{Q}_{7}$ was stationary with no significant change trends.

- The $\mathrm{Q}_{\text {med }}$ was not stationary only for the Fazenda Cacheta sub-basin, with an increase trend by approximately $2.5 \%$ per year.

- The $\mathrm{Q}_{\max }$ was not stationary only for Castelo and Iúna (IUN) sub-basins, with an increase of $2.1 \%$ and $1.6 \%$ a year, respectively.

- The precipitated total exerted a strong influence on the flows of the studied sub-basins.

- Annual rainfall $\left(\mathrm{P}_{\mathrm{a}}\right)$ significantly explained the variations of $\mathrm{Q}_{\mathrm{med}}$ and of $\mathrm{Q}_{7}$ in approximately $91 \%$ and $73 \%$ of the sub-basins, respectively.

- Rainfall in the wettest months $\left(\mathrm{P}_{\max }\right)$ significantly explained $\mathrm{Q}_{\max }$ variations in approximately $73 \%$ of the subbasins.

\section{ACKNOWLEDGMENTS}

The authors thank the Foundation for Support to Research and Innovation of Espírito Santo (FAPES) for financial support (processes 66690528 and 80709583/18); and CNPq for the concession of a research productivity grant (process 304916 / 2017-0).

\section{REFERENCES}

AGÊNCIA NACIONAL DE ÁGUAS. Sistema de Informação Hidrológicas - Hidroweb. Disponível em: <www.hidroweb.ana.gov.br>. Acesso em: 3 fev. 2016.

ALVARES, C. A.; STAPE, J. L.; SENTELHAS, P. C.; GONÇALVES, J. L. DE M.; SPAROVEK, G. Köppen's climate classification map for Brazil. Meteorologische Zeitschrift, v. 22, n. 6, p. 711-728, 2013. DOI: 10.1127/0941-2948/2013/0507.

ARAUJO, R. DA C. DE; OLIVEIRA, R. C. Estudo da Ocorrência de Mudanças Temporais na Precipitação e Descarga da Sub-bacia do Rio Itacaiúnas, Sudeste da Amazônia. Revista Brasileira de Geografia Física, v. 6, n. 2, p. 148-156, 2013.

ÁVILA, A.; JUSTINO, F. B.; WILSON, A.; BROMWICH, D.; AMORIM, M. Recent precipitation trends, flash floods and landslides in southern Brazil. Environmental Research Letters, v. 11, n. 11, p. 114029, 2016.

BARBOSA, S. E. DA S.; BARBOSA JÚNIOR, A. R.; SILVA, G. Q. DA; CAMPOS, E. N. B.; RODRIGUES, V. DE C. Geração de modelos de regionalização de vazões máximas, médias de longo período e mínimas de sete dias para a bacia do Rio do Carmo, Minas Gerais. Engenharia Sanitária e Ambiental, v. 10, n. 1, p. 64-71, 2005.

COElHO, G.; PONTES, L. M.; BATISTA, M. L.; MELlO, C. R. DE; SILVA, A. M. DA. Relação entre o escoamento de base e os diferentes sistemas hidrogeológicos do Estado de Minas Gerais. Águas Subterrâneas, v. 29, n. 3, p. 257, 2015. DOI: 10.14295/ras.v29i3.27977.

CRUZ, J. C.; TUCCI, C. E. M. Estimativa da disponibilidade hídrica através da curva de permanência. Revista Brasileira de Recursos Hídricos, v. 13, n. 1, p. 111-124, 2008. DOI: 10.21168/rbrh.v13n1.p111-124.

DIAS, L. C. P.; MACEDO, M. N.; COSTA, M. H.; COE, M. T.; NEILL, C. Effects of land cover change on evapotranspiration and streamflow of small catchments in the Upper Xingu River Basin, Central Brazil. Journal of Hydrology: Regional Studies, v. 4, n. PB, p. 108-122, 2015. DOI: 10.1016/j.ejrh.2015.05.010. 
DO, H. X.; WESTRA, S.; LEONARD, M. A global-scale investigation of trends in annual maximum streamflow. Journal of Hydrology, v. 552, p. 28-43, 2017. DOI: 10.1016/j.jhydrol.2017.06.015.

ESPINOZA VILLAR, J. C.; GUYOT, J. L.; RONCHAIL, J.; COCHONNEAU, G.; FILIZOLA, N.; FRAIZY, P.; LABAT, D.; OLIVEIRA, E. DE; ORDOÑEZ, J. J.; VAUCHEL, P. Contrasting regional discharge evolutions in the Amazon basin (1974-2004). Journal of Hydrology, v. 375, n. 3-4, p. 297-311, 2009. DOI: 10.1016/j.jhydrol.2009.03.004.

FREDERICE, A.; BRANDÃO, J. L. B. Efeito do Sistema Cantareira sobre o regime de vazões na bacia do rio Piracicaba. Revista Brasileira de Recursos Hídricos, v. 21, n. 4, p. 797-810, 2016. DOI: 10.1590/23180331.011615150 .

GASPARINI, K. A. C. Regionalização de vazões para a Bacia Hidrográfica do Rio Itapemirim, ES. [s.1.] Universidade Federal do Espírito Santo, 2014.

HOEKSTRA, A. Y.; MEKONNEN, M. M.; CHAPAGAIN, A. K.; MATHEWS, R. E.; RICHTER, B. D. Global Monthly Water Scarcity: Blue Water Footprints versus Blue Water Availability. PLoS ONE, v. 7, n. 2, p. e32688, 2012. DOI: 10.1371/journal.pone.0032688.

KREPPER, C. M.; GARCÍA, N. O.; JONES, P. D. Low-frequency response of the upper Paraná basin. International Journal of Climatology, v. 28, n. 3, p. 351-360, 2008. DOI: 10.1002/joc.1535.

LATUF, M. DE O. Mudanças no uso do solo e comportamento hidrológico nas bacias do rio Preto e ribeirão Entre Ribeiros. [s.1.] Universidade Federal de Viçosa, 2007.

MARENGO, J. A. Água e mudanças climáticas. Estudos Avançados, v. 22, n. 63, p. 83-96, 2008.

MELLO, E. L. DE; OLIVEIRA, F. A.; PRUSKI, F. F.; FIGUEIREDO, J. C. Efeito das mudanças climáticas na disponibilidade hídrica da bacia hidrográfica do rio Paracatu. Engenharia Agrícola, v. 28, n. 4, p. 635-644, 2008.

MELO JÚNIOR, J. C. F. DE; SEDIYAMA, G. C.; FERREIRA, P. A.; LEAL, B. G. Determinação de regiões homogêneas quanto à distribuição de freqüência de chuvas no leste do Estado de Minas Gerais. Revista Brasileira de Engenharia Agrícola e Ambiental, v. 10, n. 2, p. 408-416, 2006. DOI: 10.1590/S1415-43662006000200023.

MINUZZI, R. B.; SEDIYAMA, G. C.; BARBOSA, E. DA M.; MELO JÚNIOR, J. C. F. DE. Climatologia do comportamento do período chuvoso da região sudeste do Brasil. Revista Brasileira de Meteorologia, v. 22, n. 3, p. 338-344, 2007. DOI: 10.1590/S0102-77862007000300007.

PETTitT, A. N. A Non-Parametric Approach to the Change-Point Problem. Applied Statistics, v. 28, n. 2, p. 126, 1979. DOI: $10.2307 / 2346729$.

REIS, J. A. T. DOS; CAIAdO, M. A. C.; BARbOSA, J. F.; MOSCON, M.; MENDONÇA, A. S. F. Análise regional de vazão mínima de referência na Região Centro-Sul do Estado do Espírito Santo. Revista CIATECUPF, v. 5, n. 2, p. 1-11, 2013. DOI: 10.5335/ciatec.v5i2.3161.

RODRIGUEZ, D. A.; TOMASELLA, J.; LINHARES, C. Is the forest conversion to pasture affecting the hydrological response of Amazonian catchments? Signals in the Ji-Paraná Basin. Hydrological Processes, v. 24 , n. 10, p. 1254-1269, 2010. DOI: 10.1002/hyp.7586.

SALEMI, L. F.; GROPPO, J. D.; TREVISAN, R.; MORAES, J. M. DE; FERRAZ, S. F. DE B.; VILLANI, J. P.; DUARTE-NETO, P. J.; MARTINELLI, L. A. Land-use change in the Atlantic rainforest region: Consequences for the hydrology of small catchments. Journal of Hydrology, v. 499, p. 100-109, 2013. DOI: 10.1016/j.jhydrol.2013.06.049.

SANTOS, E. H. M. DOS; GRIEBELER, N. P.; OLIVEIRA, L. F. C. DE. Relação entre uso do solo e comportamento hidrológico na Bacia Hidrográfica do Ribeirão João Leite. Revista Brasileira de Engenharia Agrícola e Ambiental, v. 14, n. 8, p. 826-834, 2010.

SEN, P. K. Estimates of the Regression Coefficient Based on Kendall's Tau. Journal of the American Statistical Association, v. 63, n. 324, p. 1379-1389, 1968. DOI: 10.1080/01621459.1968.10480934.

SENA, J. P. DE O.; LUCENA, D. B. Identificação de tendência da precipitação na microrregião do Cariri Paraibano. Revista Brasileira de Geografia Física, v. 6, n. 5, p. 1400-1416, 2013. 
FLORESTA, Curitiba, PR, v. 49, n. 2, p. 171-180, abr/jun 2019 Mendes. N. G. S. et.al.

Electronic ISSN 1982-4688 DOI: $10.5380 /$ rf.v49 i 2.53994 